\title{
Læsefrugter på litteraturens mark
}

Louise Svanholm: Verdens bedste bestsellers. Aarhus Universitetsforlag 2017, 275 sider, $299,95 \mathrm{kr}$.

Jeg undrede mig, da jeg første gang så titlen på Louise Svanholms bog. For en bestseller, troede jeg, var en betegnelse for en bog, der solgte i stakkevis i løbet af kort tid. Hvordan kunne en sådan kvantitetsbetegnelse gå hånd i hånd med superlativen 'bedste' - ovenikøbet i dens mest emfatiske betydning som 'verdens bedste'? Tja, det kunne vel lade sig gøre, hvis titlens 'bedste bestsellers' skulle forstås som en markering af, at der var tale om de allerbedst sælgende bøger i hele verden. Eller omvendt: Titlen kunne også pege på, at den populære bestseller og den litterære kvalitetsbog ikke var hinandens modsætninger. Og dermed, at Verdens bedste bestsellers handlede om intet ringere end verdens ti bedste, bedst sælgende bøger.

Således optændt af iver kiggede jeg videre på bogens omslagsbillede, der viser den belgiske maler Alfred Stevens' Jeune femme lisant (1856). Maleriet antyder et muligt svar på spørgsmålet om, hvad det er, der gør en bog til en publikumsmagnet, anbefalet fra læser til læser, nemlig læselysten. Den unge kvinde i elegant musselinkjole har forglemt sig selv og verden omkring sig. Hun er fuldstændig opslugt af sin bog og det univers, den har åbnet for hende. Samtidig udpeger maleriet, tilsigtet eller utilsigtet, to aspekter, der angår læsning og bestsellerfænomenet. Dels et socialt, idet det kræver tid og overskud at hengive sig til læsningens glæder. Dels et kønsmæssigt, fordi det siden masselitteraturens fremkomst i 1700-tallet især har været kvinder, der har ladet sig fornøje af den underholdende lekture. Ikke fordi der er noget i vejen med underholdende litteratur. For som Brandes skriver i essayet "Om Læsning", gælder det, at "selv om Læsningen kun bringer os en uskyldig Underholdning, saa er selv dette af Værd under Dagliglivets Kedsomhed og ensformige Anstrengelse. Ren Morskabslæsning er ingenlunde at foragte - naar den blot morer."

\section{Valget}

Jeg åbner bogen og ser, hvilke værker der i indholdsfortegnelsen angives som verdens bedste bestsellere. Og bliver overrasket, både over udvalget og det occidentale perspektiv. Top 10-listen består af Goethes Den unge Werthers lidelser (Tyskland), Johanna Spyris Heidi (Schweiz), Mary Shelleys Frankenstein og Tolkiens Ringenes Herre (England), Flauberts Madame Bovary og Saint-Exupérys Den Lille Prins (Frankrig), Harriet Beecher Stowes Onkel Toms Hytte (USA), Khaled Hosseinis Drageløberen (Afghanistan-USA) og Murakamis Kafka på stranden (Japan). Samt endelig Sven Hazels De fordømtes legion (Danmark). 
Det er altså disse ti romaner fra en overvejende vestlig kulturkreds, der, hvis titlen skal tages for pålydende, udgør de bedste bestsellere i hele verden, i Burkina Faso såvel som i Honduras og Tasmanien. Og det ikke blot i nutiden, men over et tidsspand på 240 år, fra 1773 til 2013.

Værkernes tidsmæssige spredning indicerer imidlertid, at udvalget ikke udelukkende er bestemt af antal solgte eksemplarer. Det er ikke vor tids hurtigsælgende J.K. Rowlings Harry Potter (450 mill.), Dan Browns Da Vinci mysteriet (149 mill.) eller E.L. James' Fifty Shades of Grey-trilogien (125 mill.), der behandles. Ej heller er det en kinesisk bestsellerforfatter som Mai Jia, der af The New York Times kaldes for "perhaps the most widely read writer you've never heard of".

Selv om det kvantitative kriterium spiller en rolle i udvælgelsen af værkerne - alle har de "solgt mellem 20 og 185 millioner eksemplarer på verdensplan" - er det ikke salgstallene, der i sig selv kvalificerer dem til verdens bedste bestsellere. For de værker, Louise Svanholm analyserer og diskuterer, kan for fleres vedkommende lige så godt eller endog bedre kategoriseres som longsellers end som bestsellere. Eller begge dele som Ringenes Herre, der i løbet af 63 år har solgt 150 millioner. Ud fra en traditionel litterær betragtning hører hovedparten - Hazels De fordømtes legion på nær og måske også Hosseinis Drageløberen - snarere hjemme på lister over kanoniserede værker og klassikere end på bestsellernes Top 10.

Indholdsfortegnelsen rejser videre et par spørgsmål. Hvorfor er der alene tale om romaner? Findes der ingen bestsellere inden for lyrikken eller dramaet? Og hvorfor er der alene tale om skønlitteratur? Er det et implicit kriterium for bestsellere? Hvis ikke, er Bibelen da en bestseller? Kapitalen? Eller for den sags skyld Pixi-bøgerne, hvis det er antallet af solgte eksemplarer, der kvalificerer til betegnelsen bestseller?

Jeg giver mig i kast med første kapitel i forventning om der at få en definition af, hvad en bestseller er og en redegørelse for de kriterier, udvalget er foretaget efter. Men det får jeg ikke rigtigt. Eller dog, men det på en lidt underdrejet måde. Begrundelsen for, at valget er faldet på tysk selvmordskunst, amerikansk abolitionsagitation, schweizisk Heimatslitteratur, fransk småprinsevisdom, dansk krigsunderholdning og japansk referenceopvisning er, at værkerne "på en overraskende og bemærkelsesværdig måde er blevet bestsellere.” De er med andre ord værker, der ud fra en konventionel betragtning befinder sig på en sidevej eller på kanten af bestsellernes motorvej. Det gælder også genreperspektivet, thi ingen af dem "tilhørte [...] en formel- eller genrelitteratur, da de udkom". Altså ej heller Hazels De fordømtes legion. Dog forbliver det i krudtrøgen, på hvilken måde legionærerne underminerer eller overskrider krigsromanens konventioner. Derudover er værkerne valgt, fordi de ved deres fremkomst "udfordrede tidens tankesæt og følelsesverdener" og var "i stand til at gribe deres læsere og skabe troværdige parallelverdener, der gjorde læserne i stand til at gå deres egen virkelighed i møde.” Dette kvalitative kriterium kan ikke siges at være et distinktivt træk ved bestselleren, men gælder for al læseværdig litteratur.

\section{Bestselleren}

Selve bestsellerfænomenet forbliver uforklaret, som også kapiteloverskriften "Bestsellerens gåde" tilsiger. Bestsellerens hemmelighed eller opskrift lader sig ikke udgrunde ved hjælp af big data, som amerikanske forskere har forsøgt, ligesom det ej heller er til 
at afgøre, om det er bøgernes emner eller læserne, forlagene og markedsføringen, der skaber en bestseller. Hverken i dag eller i de århundreder, den massesælgende litteratur har spillet en rolle i det litterære kredsløb. Det eneste, der med sikkerhed kan siges om en bestseller, er, at den indeholder en spids uudgrundelighed, der tilsat tilfældigheders spil mirakuløst viser sig at være i samklang med tidsånden, hvis pulsslag det ikke altid er forlæggere beskåret at mærke. Således vandrede Rowling med Harry Potter i hånden fra forlag til forlag ligesom Brown og da Vinci, før de genererede verdenshistoriske overskud i bogbranchen.

Tilbage står dog, at kendetegnet ved en bestseller er, at den har mange læsere. Til at registrere, hvor mange det er, er bestsellerlisterne uanvendelige. Lige fra de første lister i The Bookman i 1895 og frem til i dag er bøger, der sælges fra forlag, som udgiver såkaldt kiosk- eller kulørt litteratur, ikke medtaget på listerne. At det ikke er uden betydning, har Louise Svanholm et interessant eksempel på, nemlig Patricia Highsmiths lesbiske kærlighedsroman The Price of Salt (1952). Den udkom først på et mellemstort forlag uden at sælge imponerende, dernæst blev den genudgivet på et pulpforlag og solgt i milliontal i kiosker og pr. postordre. Uden at den af den grund kom på bestsellerlisterne, men det skulle den komme. For kioskbaskeren bevægede sig nemlig ind i et kvalitetsforlags katalog, hvor den under titlen Carol fik status af nyklassiker og - via filmatisering og Oscartildeling - bestsellerstatus. Den litterære smag og læsernes sensibilitet havde ændret sig, og det, der før var det argeste svineri, var nu det pureste guld. Bestsellernes veje er i sandhed uransagelige.

Det nærmeste, Louise Svanholm kommer på en definition af det fænomen, hendes bog handler om, er det lidt kryptiske: "Bestselleren er som Udyret. For voldsom, for aparte og på mange måder ude af proportioner i kritikernes øjne" og "Bestsellere kan være både prisvindende og alment populære bøger. Bestselleren er en anomali og en såkaldt sort svane." Metaforikken kan ikke, så vidt jeg kan skønne, tjene som almen karakteristik af bestselleren, men nok af de ti værker, der analyseres og diskuteres i Verdens bedste bestsellere. Måske er Louise Svanholms bestsellere snarere eksempler på Læsefrugter, samlede på masselitteraturens markedsplads. For lige som bogtrykkeren A.F. Elmquists tidsskrift Læsefrugter, samlede paa Literaturens Mark i 1820'erne var en blandet landhandel af åndelig føde af uens bonitet og smag, er Verdens bedste bestsellere det også. Dengang var læsefrugternes store tiltrækning, at de vakte læselysten. Det gælder også Louise Svanholms frugtkurv.

\section{Læsefrugter}

De ti kapitlers læsninger er hver for sig og tilsammen fulde af smag og kraft. Der er punkteringer af myter, som at Den unge Werthers lidelser skulle have fået læserne til med Goethes egne ord at "forvandle digtningen til virkelighed og skyde sig selv". Det var ikke, viser Louise Svanholm, Werthers $\mathrm{d} ø \mathrm{~d}$ for egen hånd, der gjorde den omsiggribende Werther-feber farlig, men hans følsomme sjæl og radikale frihedstrang.

Med Mary Shelleys Frankenstein analyseres, hvad der sker med den skønne sjæl, når den har bolig i en hæslig krop. Frankensteins monstrøse, men blide og dannede skabning, som aldrig får et navn, udstødes af det menneskelige fællesskab og bliver ond.

I de sidste årtier af 1800-tallet blev Frankenstein en politisk allegori på det ufri og forkrøblede Irland, som, skriver Louise Svanholm, "konservative englændere ikke ville give 
[...] selvstændighed". Via en analogi - "på samme måde [...] ville amerikanerne heller ikke afskaffe slaveriet" - gives stafetten videre til Harriet Beecher Stowes Onkel Tom og beretningen om den sagtmodige og trofaste slave, der gengælder ondt med godt. Gennem sin umådelige evne til at udholde lidelse harmes læserne over Onkel Toms skæbne. Med Onkel Toms hytte leverede Stowe et følelsesappellerende bidrag til kravet om slaveriets afskaffelse, samtidig med at hun, som Louise Svanholm pointerer, skrev "kvinden ind i Amerikas politiske historie."

I Europa drømte middelklassekvinden Madame Bovary sig modsat væk i kulørte kærlighedsromaner. Eller rettere: Emma Bovary flygtede i realiteten ikke så meget ind i underholdningsromanen som ud af den. Det, hun begærede, var, at livet skulle være som den litteratur, hun var fortryllet af: Luksuriøst, lidenskabeligt og lykkeligt. Alt andet end det, der var hendes virkelighed som en provinslæges hustru med beskeden husførelse. "Hvor hjemmet for Werthers Lotte og Onkel Tom", understreger Louise Svanholm, "repræsenterede det frie rum for følelsesmæssig og intellektuel udfoldelse", er det for Emma Bovary et trivialiteternes trummerum. Som Werther begår hun selvmord. Men ikke som ham i afklaret fortvivlelse, men som følge af et permanent selvbedrag. Manglen på selvindsigt kaldte Jules de Gaultier i 1892 for bovarysme og gjorde den sygelige virkelighedsflugt til en tidsalders kendetegn. Hvordan det kan føre Louise Svanholm videre til Lacan og hans sammenbinding af bovarysme med barnets identitetsdannende spejlfase, forstår jeg ikke helt.

Kapitlet om Johanne Spyris Heidi-bøger kaldet "Heidegger for børn" er en fremstilling af bjergtagelsen af en autentisk tilværelse i fred og harmoni med naturen, langt fra det falske liv i de store byer. Det fører receptionshistorisk Heidi durk ind i nazismen, men Louise Svanholm fastholder hende i dannelsestankens figur og som en fornuftig storesøster til Pippi Langstrømpe. Og lader hende efterfølges af Saint-Exupérys Den Lille Prins "den tredje mest oversatte bog i verden efter Bibelen og Kapitalen af Karl Marx". Der er intet at indvende mod Louise Svanholms gennemgang af fablens visdom eller af de diskussioner, den har affødt. Selv har jeg svært ved at forstå, hvad det særlige er ved dens filosofi, som gør, at den har solgt 185 millioner eksemplarer. Måske er det, fordi den er blevet indkøbt som klassesæt i skoler, og elever i hele verden tvunget til at annamme budskaber som "Det er kun med hjertet, man kan se klart", eller "Det væsentlige er usynligt for øjet."

Den underliggende røde tråd, der forbinder flere af de udvalgte værker tematisk, er den individorienterede dannelses- eller udviklingstanke - også når den mislykkes. Det gælder også ikke-vestlige værker som Murakamis Kafka på stranden med dens fokus på "den svære hjemløse periode". Således træder et vestligt tankesæt frem som hegemonisk og rejser det spørgsmål, om bestsellere for at blive verdens bedste må formes i overensstemmelse hermed.

Disse bemærkninger forklejner ikke, at Louise Svanholms analyser af de udvalgte bestsellere og deres virkningshistorie alle er til læserens gavn og glæde.

Anmeldt af Lis Norup 